\title{
Reviewer Acknowledgements for Global Journal of Health Science, Vol. 13, No. 12
}

Global Journal of Health Science wishes to acknowledge the following individuals for their assistance with peer review of manuscripts for this issue. Their help and contributions in maintaining the quality of the journal are greatly appreciated.

Global Journal of Health Science is recruiting reviewers for the journal. If you are interested in becoming a reviewer, we welcome you to join us. Please contact us for the application form at: gjhs@ccsenet.org.

\section{Reviewers for Volume 13, Number 12}

António Calha, Polytechnic Institute of Portalegre, Portugal

Evangelia Mavrikaki, National \& Kapodistrian University of Athens, Greece

Gavric Zivana, University Banja Luka, Bosnia and Herzegovina

Hülya YARDIMCI, Ankara University, Turkey

Kartheek R Balapala, University Tunku Abdul Rahman, Malaysia

Loray Daws, British Columbia Masterson Institute, Canada

Pedram Iranmanesh, Dentist, Independent Researcher, Iran

Pi-Ming Yeh, Missouri Western State University, United States

Pranshu Sahgal, Harvard Medical School, United States of America

Robert Sloan, Kagoshima University Graduate School of Medical and Dental Sciences, Japan

Samir M. Othman, Hawler Medical University, Iraq

Soontareeporn Meepring, Naresuan University, Thailand

Tawheda El-saidy, Menoufia University, Egypt

Thammanard Charernboon, Thammasat University, Thailand

Thandiwe Marethabile Letsie, University of the Free State, South Africa

Tulyakul Phatcharapon, Boromarajonani College of Nursing, Thailand 